\title{
Carta de Caxambu/2001 À sociedade brasileira e às autoridades constituídas
}

No ano em que realiza sua $24^{a}$ Reunião Anual, com o tema Intelectuais, conhecimento e espaço público, a ANPEd manifesta-se comprometida com a instalação de novo contrato social que fortaleça a democracia, tornando o tecido social mais resistente, porque sua tessitura está sendo tramada, sobretudo pela aliança entre movimentos e organizações.

Vive-se um colapso que atravessa a sociedade. Colapso decorrente da exacerbação do modelo neoliberal, bem como das graves conseqüências advindas das políticas empreendias pelo Estado mínimo, o que vem resultando na polarização não só entre países ricos e pobres, mas também entre pobres e ricos de cada país.

O ajuste de nosso país aos condicionantes do modelo neoliberal, levado a efeito pelo governo instalado no poder há sete anos, impôs à nação um quadro marcado por um perverso processo de exclusão social.

Entre as respostas múltiplas que se ampliam como perspectivas de superação desse quadro, configura-se o fortalecimento de movimentos organizados da sociedade civil, base para a construção de novo contrato social.

Espera-se desse novo contrato a superação do processo de despolitização das relações sociais, o que exige o redimensionamento das atuais formas de regulação e gestão do Estado brasileiro.

Requer, por sua vez, que o aviltamento e a deterioração da educação em nosso país sejam enfrentados, entre outras iniciativas, com a restauração do espaço público e a garantia de condições para a produção do conhecimento, bem como incentivo aos intelectuais que se empenham, cada vez mais, em tornar o político mais pedagógico e o pedagógico mais político.

Ao longo de sua trajetória, a ANPEd tem se pautado pelo compromisso acadêmico e político com a educação e em defesa dos interesses dos docentes, discentes, pesquisadores e pesquisadoras da área, congregados nos programas de pós-graduação.

Vem participando, ao mesmo tempo, em conjunto com outras associações e entidades, dos movimentos em defesa do espaço público em todas as esferas e pela melhoria da educação superior e da educação básica. Em particular na luta pela qualificação docente.

Reafirmando os princípios assumidos desde sua criação, a ANPEd denuncia, toma partido e acredita na possibilidade de mudança, em favor das firmes convicções do coletivo que vem representando. Essas con- 
vicções estão expressas nas históricas defesas, mais uma vez enfatizadas:

- do respeito ao espaço público, com a efetiva universalização da educação básica para crianças, jovens e adultos e da garantia de uma universidade pública e de qualidade social, em contraposição à falta de condições mínimas imposta às universidade públicas, sobretudo às universidades federais;

- da implementação de mecanismos que incorporem as contribuições que o avanço da pesquisa educacional, em seus diversos campos, vem oferecendo à sociedade brasileira;

- de condições dignas de trabalho, remuneração e carreira, formação inicial e continuada dos profissionais de todos os níveis e modalidades da educação;

- da necessidade de apoio do Ministério da Educação ao fortalecimento dos programas de pósgraduação e da pesquisa na área, garantindo a manutenção da qualidade da produção e coi- bindo a comercialização da educação superior, e, em especial, de diplomas de mestrado e doutorado;

- da implementação de políticas de ciência e tecnologia que respeitem a autonomia científica e tecnológica e contribuam para a melhoria da qualidade de vida da população brasileira.

Neste momento, no qual, em todo mundo, organiza-se um poderoso movimento contra o estado de guerra a que nos levou a política neoliberal, as pesquisadoras e os pesquisadores reunidos na $24^{a}$ Reunião Anual reafirmam, com veemência, a posição histórica de educadores e educadoras pela paz.

Finalmente, registramos que, neste momento em que a ANPEd ingressa em seu $25^{\circ}$ ano de existência, $100 \%$ das universidades federais brasileiras encontram-se em greve, na mais contundente expressão de repúdio ao descaso das autoridades constituídas com os intelectuais, o conhecimento e o espaço público.

Caxambu, 11 de outubro de 2001 